\title{
S-L-G (SOLID-LIQUID-GAS) PHASE TRANSITION OF COCOA BUTTER IN SUPERCRITICAL $\mathrm{CO}_{2}$
}

\author{
K. КокоT ${ }^{\mathrm{a}}, \mathrm{Z}$. KNEZ ${ }^{\mathrm{a}, \mathrm{c}}$ and D. BAUMAN ${ }^{\mathrm{b}}$ \\ a University of Maribor, Faculty of Chemistry and Chemical Engineering, Smetanova 17, \\ SI-2000 Maribor. Slovenia \\ b PINUS, Chemical Works, Grajski trg 21, SI-2327 Rače. Slovenia
}

(Received: 31 August 1998; accepted: 15 December 1998)

\begin{abstract}
Phase equilibrium data (solid-liquid-gas) for cocoa butter and carbon dioxide were determined in view of their importance in design of PGSS (particles from gas saturated solutions) micronization process. The mutual solubility in the system cocoa butter/ $\mathrm{CO}_{2}$ was measured by the static-analytic method in the temperature range of $30-80{ }^{\circ} \mathrm{C}$ and pressure range of $1-30 \mathrm{MPa}$. The experiments on solid-liquid (S-L) transition for cocoa butter in the presence of carbon dioxide were performed by the modified capillary method in a high pressure optical cell. For the production of finely dispersed cocoa butter by expanding $\mathrm{CO}_{2}$-saturated solutions, the initial guess indicates that the starting conditions should be near the liquefaction curve in order to allow the solid-liquid region to be reached after expansion.
\end{abstract}

Keywords: Solid-liquid-gas phase transition; cocoa butter; supercritical carbon dioxide.

For the design of processes with supercritical fluids developed on industrial or research scale, solubility or phase equilibria data are very important. Recently, supercritical fluids have been applied as solvents for non extractive applications in high pressure micronisation processes. Many substances are extremely unstable under conventional conditions and the product is contaminated with residual solvent. At the same time waste solvent streams are also produced. Supercritical fluids can therefore be used as an excellent agent for micronisation process. The process for the production and fractionation of fine particles from gas saturated solutions (PGSS) consists of dissolving the substance which has to be produced and fractionated in a medium under pressure followed by the expansion of the obtained gas saturated solution and the separation of the obtained particles from gas (WEIDNER et al., 1997c). Through the choice of the appropriate combination of solvent and operating conditions suitable for a particular compound, PGSS can eliminate some of the disadvantages of traditional

\footnotetext{
${ }^{c}$ To whom the correspondence should be sent. Phone: $+386 / 62 / 2294$ 461; fax: $+386 / 62 / 22$ 77 74, E-mail:
} ZELJKO.KNEZ@UNI-MB.SI 
methods of particle size redistribution in material processing. Solid formation by PGSS, therefore shows great potential for the production of crystalline and amorphous powders with narrow and controllable size distribution.

Cocoa butter (CB) is a vegetable fat, present in chocolate at levels up to $40 \%$. Cocoa butter is a complex compound, containing different types of triglycerides. The characteristic physical properties of cocoa butter are related to the arragement of the fatty acids in the triglycerides: there is a high content of symmetrical monounsaturated triglycerides, which have the unsaturated fatty acid in position 2 and saturated fatty acids in the position 1- and 3, respectively. These triglycerides consist of 2-oleoyl-1palmitoyl-3-stearoylglycerol (POS), 2-oleoyl-1,3-distearoylglycerol (SOS), and 2oleoyl-1,3-dipalmitoylglycerol (POP), with POS being present in the largest amount. The melting behaviour of cocoa butter can be related to the melting points of these major triglycerides (POS, SOS, POP). Each of these triacylglycerols is polymorphic, they can solidify in various crystallographic forms. The process of solidification of cocoa butter is more complex than in the case of other fats. It can crystallize in five different polymorfic forms, each with its own melting point. The melting points of the major polymorfic forms (in order of increasing stability) are: $\gamma\left(16-18^{\circ} \mathrm{C}\right), \alpha$ $\left(21-24^{\circ} \mathrm{C}\right), \beta_{1}\left(27-29^{\circ} \mathrm{C}\right), \beta\left(34-35^{\circ} \mathrm{C}\right)$ and $\beta_{2}\left(36-37^{\circ} \mathrm{C}\right)$. Phase $\beta$ is always stable below its melting temperature, but its kinetics of nucleation and growth is very slow, so that under direct cooling a less stable phase is generally formed (ROUSSET et al., 1996). The hardness of cocoa butter and crystallinity has a major effect on organoleptic characteristics of chocolate.

Several authors (BHASKAR et al., 1996; Li et al., 1992; MAJEWSKI et al., 1994; SEBALD et al., 1996) have studied the solubility of cocoa butter in supercritical fluids (SCF's) because of its relevance to fractionation as well as extraction of cocoa butter from cocoa beans.

The possibility of cocoa butter micronization with supercritical carbon dioxide $\left(\mathrm{SC}-\mathrm{CO}_{2}\right)$ has not been explored yet. No value on phase equilibrium solid-liquid for the binary system cocoa butter/ $/ \mathrm{CO}_{2}$ and for the equilibrium solubility data of $\mathrm{CO}_{2}$ in the liquid phase of cocoa butter can be found in the literature.

Solid-liquid-gas phase transition: Solid-liquid-gas (S-L-G) equilibria are of great technical interest, because they form the basis for the design of several particle formation processes using dense fluids (MATSON et al., 1987; DebenEDETTI, 1990; DiXON et al., 1993). At the moment four processes are known:

- Particles from gas saturated solutions (PGSS);

- Rapid expansion of supercritical solutions (RESS);

- Gas antisolvent recrystallization (GASR), and

- Crystallization from supercritical solutions (WEIDNER et al., 1997). 
In all processes it is very important to understand the influence of pressure on the melting point of the substance in the presence of gas and phase equilibrium data of the system. The first type with a negative slope $\mathrm{dP} / \mathrm{dT}$ is found for the system where the supercritical gas has a relatively high solubility in the molten heavy component (ARONS et al., 1963). In the second type, the three-phase curve shows a temperature minimum (TuminelLo et al., 1995). The third type of solid-liquid-gas (S-L-G) lines is for systems, where the supercritical fluids are only slightly soluble in the molten heavy component, and therefore the increase in hydrostatic pressure raises the melting temperature (WEIDNER et al., 1997a). The mutual solubility in binary system of cocoa butter/ $\mathrm{CO}_{2}$ is influenced by pressure and temperature (KUMAR et al., 1988; CHRASTIL, 1982; KNEZ et al., 1992).

Solid-liquid-gas (S-L-G) line for the cocoa butter- $\mathrm{CO}_{2}$ system in P-T projection belongs to the category of binary solid-SCF fluid systems with a temperature minimum (CHEONG et al., 1986).

\section{Materials and methods}

\subsection{Materials}

Pure prime pressed cocoa butter was obtained from LEX - Portorož, Slovenia (CAS number 8008-31-1). The melting point was $32.1{ }^{\circ} \mathrm{C}$ (confirmed by DSC method). Carbon dioxide (purity 99.97\%) was kindly donated by Linde Plin Celje, Slovenia.

\subsection{Methods}

1.2.1. Determination of melting point under the pressure of $\mathrm{CO}_{2}$. The values of melting points were determined by the modified capillary method. The method used to determine the melting point of a substance in the presence of gas under pressure is similar to one used at atmospheric pressure. A glass capillary tube is filled with the substance in question and inserted into a high pressure view cell along with the thermocouple. Fig. 1 gives a schematic drawing of the equipment for the determination of melting points under the pressure of supercritical fluids.

An optical cell with a volume of $14 \mathrm{ml}$ was used (NWA GmbH, Lörrach, Germany); this cell can operate at pressures up to $50 \mathrm{MPa}$ and temperatures up to $250{ }^{\circ} \mathrm{C}$. The cell has two saphire windows which are fixed to the cell with screws. There are also three openings, one for entering the gas, one for emptying the gas, and one for inserting the thermocouple. The thermocouple was calibrated with some pure substances (o-nitrophenol, $\mathrm{T}_{\mathrm{m}}=45.0^{\circ} \mathrm{C}$; azobenzol, $\mathrm{T}_{\mathrm{m}}=68.0^{\circ} \mathrm{C}$; benzil, $\mathrm{T}_{\mathrm{m}}=98.0^{\circ} \mathrm{C}$; acetanilid, $\mathrm{T}_{\mathrm{m}}=115.0^{\circ} \mathrm{C}$ ) with known melting points. A standard curve was constructed and used to adjust the recorded experimental data. Pressurized gas was inserted via a 
high-pressure pump. The pressure was measured by electronic pressure manometer (Digibar PE 200 Hottinger-Baldwin to $\pm 0.1 \%$ ), and the cell was electrically heated with a heating jacket to $\pm 0.5^{\circ} \mathrm{C}$. The temperature was measured with an accuracy of $\pm 0.1{ }^{\circ} \mathrm{C}$ with a thermocouple.

The gas was inserted into the system and the temperature was raised using a heating coil. The melting of the substance was observed by a video camera. The recordings of the temperature and pressure were made at the beginning and end of melting.

In screening experiments it was observed whether the melting-temperature range depended on the mode of operation (pressure/temperature increase: "upward strategy", or pressure/temperature decrease: "downward strategy"). No hysteresis was found within the experimental accuracy $\left( \pm 0.5^{\circ} \mathrm{K}, \pm 0.05 \mathrm{MPa}\right)$.

1.2.2. Determination of liquid-vapour phase transition under the pressure of carbon dioxide. For the determination of mutual solubility in the system cocoa butter/ $\mathrm{CO}_{2}$ in the temperature range $30-80{ }^{\circ} \mathrm{C}$ and pressure range $1-30 \mathrm{MPa}$, a staticanalytic method was described in our previous work (KNEZ et al., 1995).

The $500 \mathrm{ml}$ autoclave was loaded with 150-200 $\mathrm{g}$ of cocoa butter. The $\mathrm{CO}_{2}$ from the tank was cooled to a liquid state and compressed into the equilibrium cell by a highpressure pump. The temperature in the autoclave was regulated with a heating jacket (accurate to $\pm 1.0^{\circ} \mathrm{C}$ ), and the pressure was measured by a Digibar manometer (Hotinger Baldwin Messtechnik, accuracy $\pm 0.1 \%$ ).

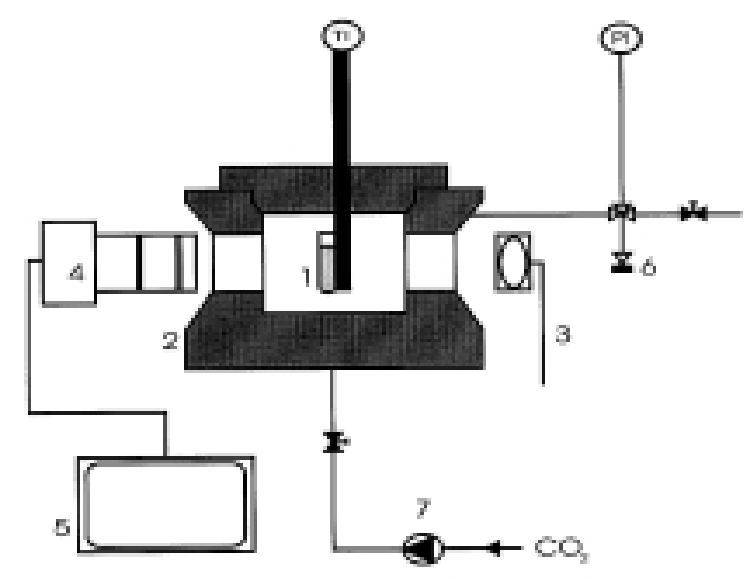

Fig. 1. Basic scheme of experimental equipment. 1: glass capillary with sample, 2: high pressure cell, 3: lamp, 4: video camera, 5 : computer, 6 : safety valve, $7:$ high pressure pump 
Because of the spinodal and binodal effects (WEIDNER et al., 1997b), different values were obtained when the pressure in the system was increased or decreased. In all cases where "upward strategy" was applied, $\mathrm{CO}_{2}$ had to diffuse into the unsaturated liquid. The binary mixture was mixed and equilibrium was established. After $1 \mathrm{~h}$ of phase separation, samples of the lower phase (rich in cocoa butter) and the upper phase (rich in $\mathrm{CO}_{2}$ ) were taken. The amount of $\mathrm{CO}_{2}$ released was measured by a flow meter (Elser-type, $\phi= \pm 2 \%$ ), and the mass of cocoa butter was measured gravimetrically ( \pm $0.1 \mathrm{mg}$ ). The cocoa butter $/ \mathrm{CO}_{2}$ mass ratio was calculated for both samples.

\section{Results}

\subsection{Solid-liquid phase transition under the pressure of $\mathrm{CO}_{2}$}

The P-T projection of the solid-liquid-gas (S-L-G) equilibrium lines has been measured for binary mixture of cocoa butter/ $\mathrm{CO}_{2}$. The three-phase curve for the binary system shows a temperature minimum. The experimental data for this binary system are presented in Table 1 and Fig. 2.

Table 1

Melting points of cocoa butter under the pressure of carbon dioxide

\begin{tabular}{cc}
\hline $\begin{array}{c}\text { Mean } \\
\text { pressure } \\
{[\mathrm{MPa}]}\end{array}$ & $\begin{array}{c}\text { Mean } \\
\text { temperature } \\
{\left[{ }^{\circ} \mathrm{C}\right]}\end{array}$ \\
\hline 31.23 & 24.7 \\
24.08 & 24.6 \\
20.50 & 24.6 \\
17.88 & 24.8 \\
16.00 & 24.6 \\
14.85 & 24.7 \\
13.70 & 24.2 \\
11.15 & 23.4 \\
9.28 & 22.4 \\
7.28 & 22.3 \\
6.05 & 22.1 \\
5.98 & 22.4 \\
3.95 & 23.1 \\
3.30 & 27.1 \\
2.55 & 30.2 \\
1.65 & 30.9 \\
0.80 & 32.2 \\
0.70 & 32.4 \\
\hline 0.10 & 32.1 \\
\hline
\end{tabular}




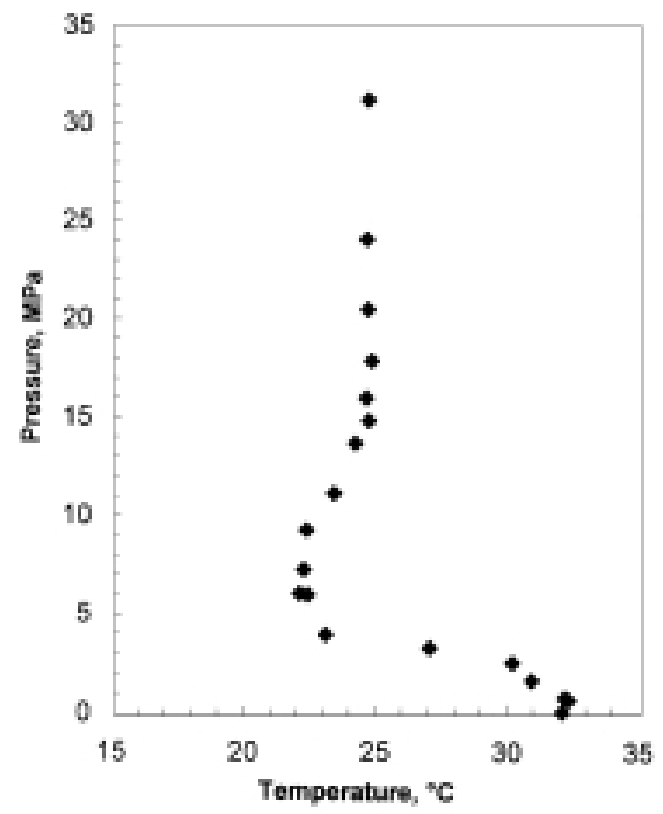

Fig. 2. P-T diagram for cocoa butter-carbon dioxide system

In Fig. 2 the mean value between the upper and lower melting temperatures is presented.

Each mean value was measured at least three times and the experimental accuracy was $\pm 0.5^{\circ} \mathrm{K}$ and $\pm 0.05 \mathrm{MPa}$. The accuracy of the method was $\pm 0.5 \%$. Because the quantity of the sample was sufficiently small compared to the volume of the equilibrium cell, further experiments could have been done after obtaining equilibrium. The reliability and efficiency of the solubility measuring technique (especially in the lower range) have been established previously by measuring the solubility of $\beta$-carotene and oleic acid in $\mathrm{CO}_{2}$ and by comparing obtained data with the literature data (ŠKKERGET et al., 1995).

For cocoa butter the liquefaction temperature increased very little when the pressure rose to about $1 \mathrm{MPa}$ as compared to the melting point at $0.1 \mathrm{MPa}$. In this pressure range (0.1-1 MPa) the solubility of $\mathrm{CO}_{2}$ in $\mathrm{CB}$ was low, and therefore no increase in the liquefaction temperature, due to the solubilized gas in $\mathrm{CB}$, was observed. At pressure higher than $1 \mathrm{MPa}$, the transition temperature of the $\mathrm{CB}$ investigated decreased. Based on the high solubility of $\mathrm{CO}_{2}$ in the molten mixture, at pressures higher than $1 \mathrm{MPa}$, the transition temperature of the cocoa butter decreased. For cocoa butter, the decrease went up to 6.05 $\mathrm{MPa}$ (from $32.1{ }^{\circ} \mathrm{C}$ at $0.1 \mathrm{MPa} \mathrm{CO}_{2}$, to $22.1{ }^{\circ} \mathrm{C}$ at $6.05 \mathrm{MPa}$ ). 
Table 2

Liquid-vapour phase equilibrium data for the binary system cocoa butter/carbon dioxide ( $\mathrm{w}=$ mass fraction of carbon dioxide, ${ }^{1}=$ liquid phase, ${ }^{\mathrm{g}}=$ gas phase)

\begin{tabular}{|c|c|c|c|c|c|c|c|}
\hline $\begin{array}{c}\mathrm{T} \\
\left({ }^{\circ} \mathrm{C}\right)\end{array}$ & $\begin{array}{c}\mathrm{P} \\
(\mathrm{MPa})\end{array}$ & $\begin{array}{c}\mathrm{w}^{1} \\
(\%)\end{array}$ & $\begin{array}{l}w^{\mathrm{g}} \\
(\%)\end{array}$ & $\begin{array}{c}\mathrm{T} \\
\left({ }^{\circ} \mathrm{C}\right)\end{array}$ & $\begin{array}{c}\mathrm{P} \\
(\mathrm{MPa})\end{array}$ & $\begin{array}{l}w^{1} \\
(\%)\end{array}$ & $\begin{array}{l}\mathrm{w}^{\mathrm{g}} \\
(\%)\end{array}$ \\
\hline \multirow[t]{23}{*}{30} & 1.50 & 2.92 & 98.89 & \multirow[t]{23}{*}{40} & 0.85 & 2.89 & 99.23 \\
\hline & 2.20 & 5.95 & 98.92 & & 2.45 & 8.90 & 99.53 \\
\hline & 3.30 & 11.86 & 95.53 & & 2.80 & 10.51 & 98.18 \\
\hline & 5.50 & 16.03 & 97.17 & & 4.00 & 12.07 & 98.30 \\
\hline & 6.65 & 28.02 & 97.21 & & 5.00 & 14.45 & 99.39 \\
\hline & 7.20 & 32.05 & 96.54 & & 6.45 & 20.84 & 99.48 \\
\hline & 8.20 & 36.95 & 95.44 & & 7.35 & 25.48 & 99.61 \\
\hline & 9.35 & 46.04 & 95.80 & & 8.15 & 22.89 & 99.89 \\
\hline & 10.95 & 41.32 & 99.12 & & 10.00 & 33.27 & 99.20 \\
\hline & 12.15 & 42.65 & 95.63 & & 12.40 & 33.27 & 96.30 \\
\hline & 12.70 & 45.84 & 97.51 & & 12.95 & 36.07 & 99.5 \\
\hline & 13.65 & 46.32 & 96.04 & & 15.55 & 39.20 & 99.70 \\
\hline & 14.70 & 44.47 & 98.71 & & 16.45 & 44.30 & 99.20 \\
\hline & 15.95 & 42.84 & 99.00 & & 18.05 & 41.10 & 98.99 \\
\hline & 17.10 & 42.52 & 98.22 & & 19.00 & 44.61 & 99.50 \\
\hline & 19.30 & 45.18 & 96.61 & & 19.40 & 43.42 & 98.89 \\
\hline & 19.95 & 44.09 & 98.35 & & 22.75 & 45.41 & 99.60 \\
\hline & 22.35 & 44.20 & 98.95 & & 24.60 & 46.22 & 99.00 \\
\hline & 23.14 & 45.11 & 99.48 & & 26.50 & 47.76 & 99.75 \\
\hline & 23.45 & 42.98 & 98.57 & & & & \\
\hline & 23.80 & 43.30 & 99.16 & & & & \\
\hline & 25.80 & 50.14 & 99.91 & & & & \\
\hline & 26.90 & 50.54 & 99.63 & & & & \\
\hline \multirow[t]{17}{*}{60} & 0.90 & 0.98 & 95.84 & \multirow[t]{17}{*}{80} & 1.00 & 1.60 & 94.00 \\
\hline & 2.35 & 4.03 & 97.65 & & 2.50 & 5.28 & 97.70 \\
\hline & 4.00 & 10.50 & 98.04 & & 3.90 & 8.44 & 96.00 \\
\hline & 5.90 & 13.27 & 94.38 & & 6.55 & 14.12 & 97.00 \\
\hline & 8.10 & 19.76 & 99.74 & & 8.30 & 21.33 & 99.26 \\
\hline & 9.90 & 26.75 & 99.87 & & 10.30 & 23.81 & 97.85 \\
\hline & 11.65 & 34.48 & 99.95 & & 12.55 & 33.48 & 97.96 \\
\hline & 14.00 & 42.23 & 99.88 & & 14.55 & 35.48 & 97.27 \\
\hline & 14.30 & 45.31 & 99.83 & & 15.90 & 37.61 & 98.82 \\
\hline & 15.75 & 43.26 & 99.97 & & 18.00 & 37.40 & 99.59 \\
\hline & 16.50 & 41.38 & 99.89 & & 20.00 & 37.26 & 99.79 \\
\hline & 18.55 & 40.22 & 99.65 & & 21.10 & 35.15 & 99.68 \\
\hline & 21.40 & 39.45 & 99.26 & & 22.30 & 36.39 & 96.72 \\
\hline & 22.60 & 40.00 & 99.70 & & 23.90 & 36.96 & 99.82 \\
\hline & 24.40 & 40.5 & 99.00 & & 26.15 & 38.02 & 99.02 \\
\hline & 26.70 & 44.49 & 98.20 & & 27.25 & 38.36 & 99.00 \\
\hline & 28.80 & 43.60 & 97.90 & & & & \\
\hline
\end{tabular}


The melting point data allows us to determine solubility due to the colligative properties of solutions (ARONS et al., 1963). This explanation is based on the fact that when a supercritical gas is pressed on a melting heavy component, there are two opposite temperature effects: because of the increase of hydrostatic pressure the melting temperature will rise (in most cases), and because the gas will dissolve in the molten heavy component there will be a melting point depression. The deviations are greater in case of higher solubility of gas in the equilibrium liquid. When SCF diffuses into substances, the melting point changes. The molecules of supercritical fluid interfere with the crystal structure of the substance and reduce the energy needed to break the intramolecular bonds.

It was concluded that the pressure effect on the solid-liquid transition outweighs the solubility effect in the pressure range from 0.1 to $1 \mathrm{MPa}$. The depression of the liquefaction temperature with the observed minimum can also be explained by the competing effects of the shrinking molar volume of $\mathrm{CO}_{2}$ and the increase in the melting point of cocoa butter due to higher pressure (Clausius-Clapeyron relationship). At lower pressure, the molar volume of $\mathrm{CO}_{2}$ decreases more rapidly with increasing pressure, and therefore in the pressure range 1-6.05 MPa this effect is dominant. In the pressure range $6.05-14.85 \mathrm{MPa}$ the liquefaction temperature slowly increases. At pressures greater than $14.85 \mathrm{MPa}$, the transition temperature is practically constant. In this pressure range, a further increase in pressure does not significantly enchance the solubility of $\mathrm{CO}_{2}$ in cocoa butter (see Fig. 3).

\subsection{Liquid-vapour phase transition under the pressure of carbon dioxide}

The experimental liquid-vapour equilibrium line for cocoa butter/ $\mathrm{CO}_{2}$ has important implications in interpreting the solubility behaviour for this system. The results of the determination of the solubility of $\mathrm{CO}_{2}$ in cocoa butter and cocoa butter in supercritical phase are presented in Table 2 and Fig. 3.

Each data point in Fig. 3 represents average of the least three measurements. The maximum deviation among the three measurements was $2.5 \%$. This deviation of $2.5 \%$ gives a good indication of the expected accuracy of the results because the individual experimental errors that contribute to the overall error (i.e. in pressure, temperature, concentration and volume) are all significantly below this level. The $2.5 \%$ variation is due to random experimental errors associated with the difficulties of working with high-pressure supercritical fluids. 


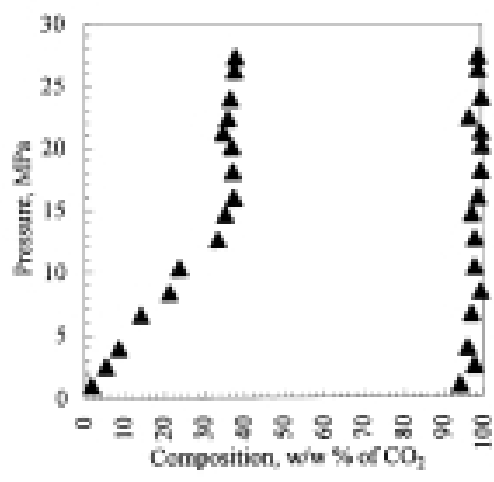

a)

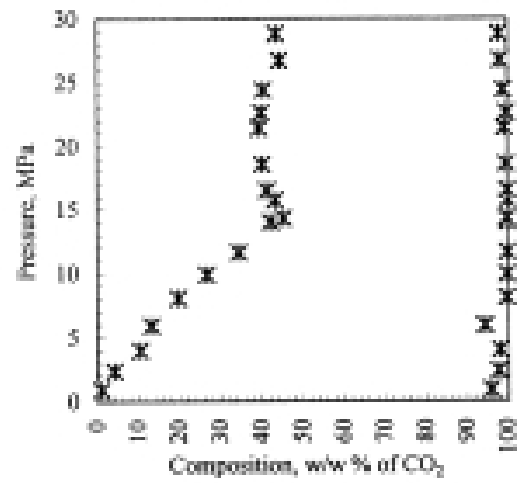

c)

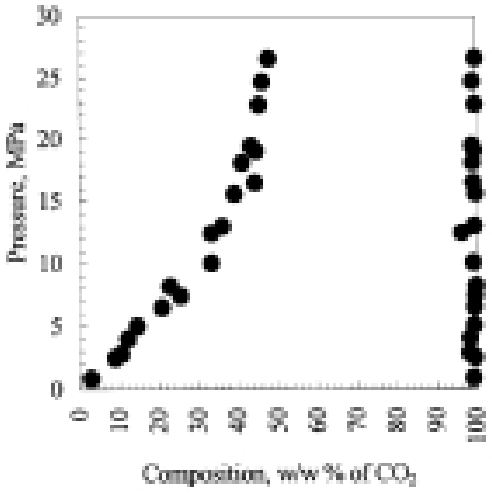

b)

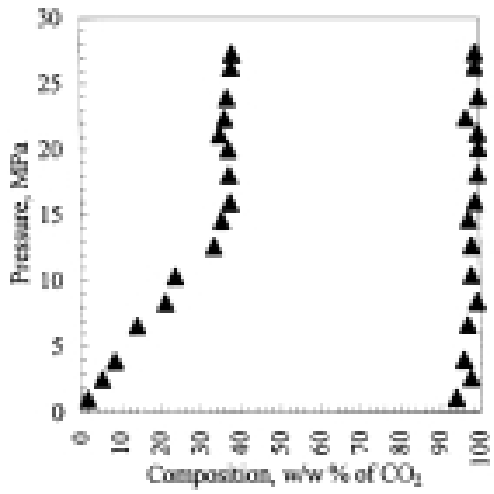

d)

Fig. 3. Equilibrium solubility data for binary system Cocoa Butter/ $\mathrm{CO}_{2}$ at: a) $\mathrm{T}=30^{\circ}(303.15 \mathrm{~K})$; b) $\mathrm{T}=40{ }^{\circ} \mathrm{C}(313.15 \mathrm{~K})$; c) $\mathrm{T}=60{ }^{\circ} \mathrm{C}(333.15 \mathrm{~K})$ and d) $\mathrm{T}=80{ }^{\circ} \mathrm{C}(353.15 \mathrm{~K})$

It is shown that the solubility of fats and oils in $\mathrm{SC}-\mathrm{CO}_{2}$ is strongly correlated to pressure and temperature (YU et al., 1992). The experimental equilibrium solubility data were determined at the temperatures of $30,40,60$ and $80^{\circ} \mathrm{C}$ and in the pressure range from 1 to $30 \mathrm{MPa}$. Temperature and pressure effect on the solubility show the usual trends. The solubility of $\mathrm{CO}_{2}$ in cocoa butter is high and the maximal equilibrium solubility is $50.5 \mathrm{w} / \mathrm{w} \%$ of $\mathrm{CO}_{2}$, at pressure $26.9 \mathrm{MPa}$ and $30{ }^{\circ} \mathrm{C}$. At constant pressure and with increasing temperature, the solubility of $\mathrm{CO}_{2}$ decreases. 
The equlilibrium solubility data are presented as a pressure-weight composition plot (Fig. 3). The solubility of $\mathrm{CO}_{2}$ in cocoa butter increases with decreasing temperature, and increases with increasing pressure. The isotherms at 40,60 and $80{ }^{\circ} \mathrm{C}$ in Fig. 3/b,c,d have practically the same equilibrium solubility values, especially at pressures lower than $15 \mathrm{MPa}$. Typical values for the concentration of cocoa butter in $\mathrm{CO}_{2}$ are lower than $5 \%$. This observation is also confirmed by the data for cocoa butter of LI and co-workers (1992) and BHASKAR and co-workers (1996).

\subsection{Pressure-temperature diagram with isopleths}

The phase equilibrium data were plotted in a P-T diagram. From the phase diagram, lines of constant liquid/vapour composition were determined and are shown in Fig. 4.

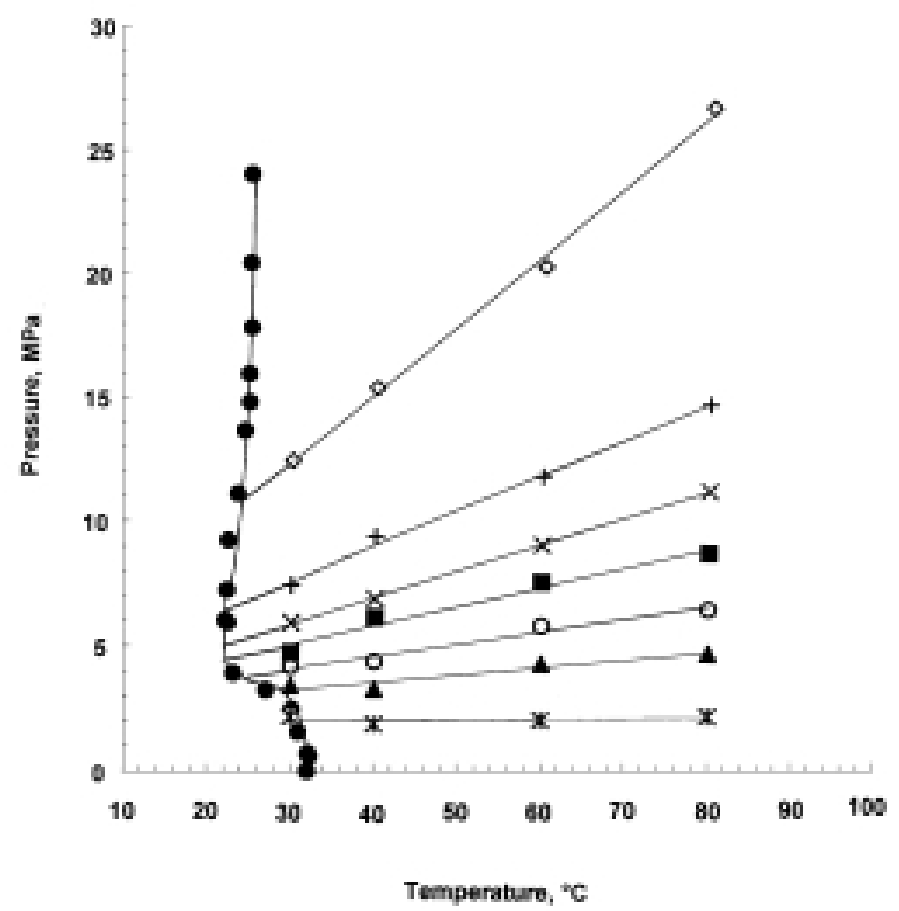

Fig. 4. P-T diagram with melting point and constant composition lines for cocoa butter. ๑: Melting curve of cocoa butter under pressure of $\mathrm{CO}_{2}, *$ : $\mathrm{w}=5 \%(\mathrm{w} / \mathrm{w}), \boldsymbol{\Delta}: \mathrm{w}=10 \%(\mathrm{w} / \mathrm{w}), \mathrm{O}: \mathrm{w}=15 \%(\mathrm{w} / \mathrm{w}), \boldsymbol{\square}: \mathrm{w}=20 \%$ $(w / w), \times: w=25 \%(w / w),+: w=30 \%(w / w), \diamond: w=45 \%(w / w)$ 
The lines of constant composition are linear functions of pressure and temperature. The slopes of constant composition lines depend on vapour pressure of a component in gas saturated solution. In a P-T projection, the vapour-liquid equilibrium is presented by the lines of constant compositions (isopleths), which are plotted as a function of the temperature.

Extrapolation of constant composition lines to the S-L line (liquefaction line, Fig. 4) shows the pressure and temperature at which a solution of cocoa butter- $\mathrm{CO}_{2}$ with a certain composition can be obtained.

\section{Conclusions}

The experimental liquid-vapour equilibrium solubilities in the binary system cocoa butter/carbon dioxide were determined at temperatures $30,40,60$ and $80{ }^{\circ} \mathrm{C}$ and at pressures ranging from 1 to $30 \mathrm{MPa}$. The effect of pressure on the mutual solubility follows the expected trends, with the solubility increasing with increasing pressure for all four temperatures studied.

Presented data are important for design of PGSS-micronisation process. From the obtained S-L-G phase transition data it can be concluded that the gas saturated solution is established at pressures and temperatures which are on the right of the liquefaction curve (S-L-G). On the left, the liquefaction curve of solid cocoa butter coexists with gaseous $\mathrm{CO}_{2}$. The starting conditions have to be chosen so that the maximum loading of $\mathrm{CB}$ with $\mathrm{CO}_{2}$ be obtained and that the final conditions after the expansion are in the $\mathrm{S}-\mathrm{V}$ region of the binary system.

The authors are grateful for the financial support of the Slovenian Ministry of Science and Technology (Project: High Pressure Technologies J2-7638 and Separation Process Development L2-8605).

\section{References}

ARONS, J. D. S. \& DIEPEN, G. A. M. (1963): Thermodynamic study of melting equilibria under pressure of a supercritical gas. Rec. Trav. Chim., (Pays-Bas), 82, 249-256.

BHASKAR, A. R., RIZVI, S. S. H. \& BERTOLI, C. (1996): Cocoa butter fractionation with supercritical carbon dioxide. -in: VON ROHR, R. PH. \& TREPP, CH. (Eds) Proceedings of the 3rd Inernational Symposium on High Pressure Chemical Engineering, October 7-9, Zürich, Switzerland, pp. 297-302.

CHEONG, P. L., ZHANG, D., OHGAK, K. \& LU, B.C.-Y. (1986): High pressure phase equilibiria for binary systems involving a solid phase. Fluid Phase Equilibria, 29, 555-562.

CHRASTIL, J. (1982): Solubility of solids and gases in suprecritical gases. J. phys. Chem., 86, 3016-3021. 
DEBENEDETTI, P. G. (1990): Homogeneous nucleation in supercritical fluids. AIChE J., 36, 1289-1298.

DIXON, D. J., JOHNSTON, K. P. \& BODMEIER, R. A. (1993): Polymeric materials formed by precipitation with a compressed fluid antisolvent. Materials, Interfaces and Electrochemical Phenomena, AIChE J., 39, 127-139.

KNEZ, Ž., ŠKERGET, M., BOŽIČ, P. S. \& RIŽNER, A. (1995): Solubility of nifedipine and nitrendipine in supercritical $\mathrm{CO}_{2}$. J. chem. \& Engng. Data, 40, (1), 216-220.

KNEZ, Ž \& STEINER, R. (1992): Solubility of capsaicin in dense $\mathrm{CO}_{2}$. J. supercrit. Fluids, 5, 251-255.

KUMAR, S. K. \& JOHNSTON, K. P. (1988): Modelling the solubility of solids in supercritical fluids with density as the independent variable. J. supercrit. Fluids, 1, 15-18.

LI, S. \& HARTLAND, S. (1992): Influence of co-solvents on solubility and selectivity in extraction of xanthines and cocoa butter from cocoa beans with supercritical $\mathrm{CO}_{2}$. J. Supercrit. Fluids, 5, 7-12.

MAJEWSKI, W., MENGAL, P., PERRUT, M. \& ECALARD, J. P. (1994): Supercritical fluid fractionation of butter oil. -in: RIZVI, S. S. H. (Ed.) Supercritical fluid processing of food and biomaterials. Blackie Academic Professional, Chapman \& Hall, London, pp. 123-132.

MAtSon, D. W., PETERSEN, R. C. \& SMTTH, R. D. (1987): Production of powders and films by the rapid expansion of supercritical solutions. J. Material Sci., 22, 1919-1928.

ROUSSET, PH. \& RAPPAZ, M. (1996): Cristallization kinetics of the pure triacylglycerols POP, POS and SOS. J.A.O.C.S., 73, 1051-1057.

SEBALD, J., SCHULMEYR, J. \& GEHRIG, M. (1996): Removal of xanthines from cacao. -in: VON ROHR, R. PH. \& TREPP, CH. (Eds) Proceedings of the 3rd Inernational Symposium on High Pressure Chemical Engineering, October 7-9, Zürich, Switzerland, pp. 333-338.

ŠKERGET, M., KNEZ, Ž. \& HABULIN, M. (1995): Solubility of $\beta$-carotene and oleic acid in dense $\mathrm{CO}_{2}$ and data correlation by a density based model. Fluid Phase Equilibria, 109, 131-138.

TuMinELlO, W. H., DEE, G. T. \& MCHUGH, M. A. (1995): Dissolving perfluoropolymers in supercritical carbon dioxide. Macromolecules, 28, 1506-1512.

YU, Z. R., RIZVI, S. S. H. \& ZOLLWEG, J. A. (1992): Fluid-liquid equilibria of anhydrous milk fat with supercritical carbon dioxide. J. supercrit. Fluids, 5, 123-129.

WEIDNER, E., KNEZ, Ž., WIESMET \& KOKOT, K. (1997a): Phase equilibrium (solid-liquid-gas) in the system polyethylenglycols-nitrogen. -in: REVERCHON, E. (Ed.) Proceedings of the 4th Italian Conference on Supercritical Fluids and their Applications, Sept. 7-10, Capri (Napoli), pp. 409-415.

WEIDNER, E., WIESMET, V., KNEZ, Ž. \& ŠKERGET, M. (1997b): Phase equilibrium (solid-liquid-gas) in polyethylenglycol-carbon dioxide systems. J. supercrtic. Fluids, 10, 139-147.

WEIDNER, E., KNEZ, Ž., \& NOVAK, Z. (1997c): Process for preparing particles or powders. EU Patent Nr. 0744992 . 